IRA-International Journal of Technology \& Engineering ISSN 2455-4480

Proceedings of the

International Conference on Science \& Engineering

for Sustainable Development (2017)

Pg. no.364-372

Published by: Institute of Research Advances

https://research-advances.org/index.php/IRAJTE

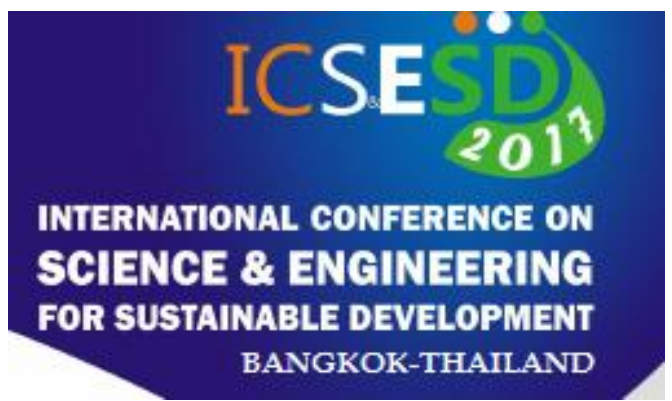

\title{
Electric Vehicles for Low Carbon Sustainable Development of Transport sector of Developing Asia
}

\section{Hemant M. Nandanpawar}

Energy, Climate Change and Sustainable Development Expert Senior Director - Advisory Services, Ernst and Young LLP, Manila, Philippines.

Type of Review: Peer Reviewed under the responsibility of the Scientific Committee of the Conference and The Institution of Engineers (India).

DOI: http://dx.doi.org/10.21013/jte.ICSESD201735

\section{How to cite this paper:}

Nandanpawar, H. (2017). Electric Vehicles for Low Carbon Sustainable Development of Transport sector of Developing Asia. Proceedings of the International Conference on Science \& Engineering for Sustainable Development (2017), 364-372. doi: http://dx.doi.org/10.21013/ite.ICSESD201735

(C) International Conference on Science \& Engineering for Sustainable Development \& The Institution of Engineers (India).

\section{(cc)) $\mathrm{BY}-\mathrm{NC}$}

This work is licensed under a Creative Commons Attribution-Non Commercial 4.0 International License subject to proper citation to the publication source of the work.

Disclaimer: The conference papers as published by the Institute of Research Advances (IRA) are the views and opinions of their respective authors and are not the views or opinions of the IRA. The IRA disclaims of any harm or loss caused due to the published content to any party. 


\section{ABSTRACT}

Transport sector is one of the largest contributors of energy related greenhouse gas (GHG) emissions globally and is expected to grow 50 percent by 2050. Controlling GHG emission growth of transport sector is necessary in view of limiting the global temperature increase to below 2 degrees Celsius, agreed under Paris Agreement, to avoid extreme Climate Change effects. Further analysis reflects that Electric Vehicles $(E V)$ have great role to play in limiting transport sector emissions.

In view of various environmental, climate change and human health related benefits, electric vehicles $(E V)$ is witnessing an increasing trend across the globe, specifically in the developed nations. However, the economics of electric vehicles as well as the physical issues such as charging infrastructure, dependence on grid connected power etc. put a constraint on the fast growth of such vehicles in both, developing and developed economies. Although the Asian developing economies typically have highest growth rate in terms of vehicles usage but due to economic or physical challenges they are unable to deploy the electric vehicles at a swift pace. The principle advantage of battery based electric vehicles is that they are zero-emission at point-of-use. It provides local environmental benefits including cleaner air and reduced noise in urban areas. Overall, EV contributes for the sustainable development of the transport sector and many developed countries have adopted such vehicles on a large scale. Global EV sales were 462,000 during 2015 and it is estimated that EVs will constitute 35\% (41 million) of new car sales by 2040. According to the IEA estimates, the US (39\%), Japan (16\%) and China (12\%) are currently the prominent EV stock holding markets globally.

This paper includes discussion on various socio economic and environmental benefits of the electric vehicles along with the challenges of its promotion in the developing economies. Further, the paper will also cover the various models for socializing electric vehicles and better adoption as well as policy and other enablers that are crucial for its promotion.

Key Words - Electric Vehicles, Sustainable Development, Low Carbon, Sustainable Transport, Environmental Benefits, Climate Change

\section{Introduction/Background}

Transport contributes almost one-quarter ( 23 percent) of the current global energy-related greenhouse gas (GHG) emissions and is growing faster than any other energy end-use sector. GHG emissions from transport are anticipated to rise from today's levels by nearly 20 percent by 2030 and close to 50 percent by year 2050 unless major action is undertaken. Limiting the global temperature increase to below 2 degrees Celsius requires changing this transport emissions trajectory, which involves the development of an integrated electro mobility ecosystem encompassing various transport modes, coupled with the lowcarbon production of electricity and hydrogen, implemented in conjunction with broader sustainable transport principles. According to the International Energy Agency, this transition will require, inter alia, pursuit of global rail transport electrification, already underway, as well as at least 20 percent of all road transport vehicles globally to be electrically driven by 2030 - if warming is to be limited to 2 degrees or less. ${ }^{1}$ Emissions from transport are the fastest growing source of $\mathrm{CO} 2$ emissions, with the vast majority of projected increases expected to come from Asian developing countries ${ }^{2}$.Asia's motorized transport emissions have become a significant contributor to the global problem of greenhouse gas (GHG)

1UNFCCC- Paris Declaration on Electro-Mobility and Climate Change \& Call to Action. Available on: http://newsroom.unfccc.int/media/521376/paris-electro-mobility-declaration.pdf

2 Asian development Bank (ADB) - Addressing Climate Change in Transport Sector of Asian Developing countries, Available on:https://www.adb.org/sectors/transport/key-priorities/climate-change 
emissions that leads to climate change. In 2009, transport was responsible for $23 \%$ of global GHG emissions compared with $41 \%$ for energy. But by 2035 transport is expected to become the single largest GHG emitter accounting for $46 \%$ of global emissions, and by 2050 it is set to reach $80 \%$. In 2006, Asia accounted for $19 \%$ of total worldwide transport-sector relatedCO2 emissions. By 2030, the share of Asia in total worldwide transport-sector related $\mathrm{CO} 2$ emissions will increase to $31 \%$.

Ambitious policy support, socialization techniques, and technologic innovations has allowed the Electric Vehicles (EV) to grow its market presence and feasibility considerable in the span of 2010-2016. ${ }^{3}$ Addressing early challenges fast in developing markets with concerted efforts, the developing world has lagged behind EV adaption due to many factors linked with industrial expansion. ${ }^{4}$ The motivations for EV adaption are a keen interest in proactively dealing with the challenges of climate change via the reducing of the use of fossil fuels through cessation of gasoline intake to influence the strength of national security and sustainability. ${ }^{5}$ While "Industry, governments and early adopters have succeeded in demonstrating that electric cars can deliver the practicality, sustainability, safety and affordability characteristics expected from them, but the EV market still requires policy support to achieve widespread adoption and deployment." 6 However, this policy support must be balanced not only with practicality, but for supporting consumer freedom.

\section{Current Status of Electronic Vehicles Promotion Internationally}

Currently 40 countries are members of the EVI, which is a policy forum established in 2009 as a part of the Clean Energy ministerial (CEM), whose goal is increasing the production and adaption of EV's around the world. The EVI counts today 16 member governments (Canada, China, France, Germany, India, Italy, Japan, Korea, the Netherlands, Norway, Portugal, South Africa, Spain, Sweden, the United Kingdom and the United States). ${ }^{7}$

\footnotetext{
${ }^{3}$ International Energy Agency, 'Global EV Outlook 2016: Beyond one million electric cars,' OECD/IEA 2016, Available on: https://www.iea.org/publications/freepublications/publication/Global_EV_Outlook_2016.pdf, (accessed 5 April 2017).

${ }^{4}$ N. Cox, 'Tesla Facing Both Challenges And Opportunities In Asia,' Seekingalpha.com, April 15, 2016. Available on: https://seekingalpha.com/article/3999759-tesla-facing-challenges-opportunities-asia, (accessed 5 April 2017).

${ }^{5}$ K.Kilday, 'Niche for Electric Vehicles in Developing Countries,' Stanford.edu, March 9, 2016, Available on: https://sej.stanford.edu/niche-electric-vehicles-developing-countries, (accessed 5 April 2017).

${ }^{6}$ International Energy Agency, 'Global EV Outlook 2016: Beyond one million electric cars,' OECD/IEA 2016, Available on: https://www.iea.org/publications/freepublications/publication/Global_EV_Outlook_2016.pdf, (accessed 5 April 2017).

${ }^{7}$ International Energy Agency, 'Global EV Outlook 2016: Beyond one million electric cars,' OECD/IEA 2016, Available on: https://www.iea.org/publications/freepublications/publication/Global_EV_Outlook_2016.pdf, (accessed 5 April 2017).
} 


\section{Figure $5 \bullet$ Country coverage of the "Global EV outlook 2016"}

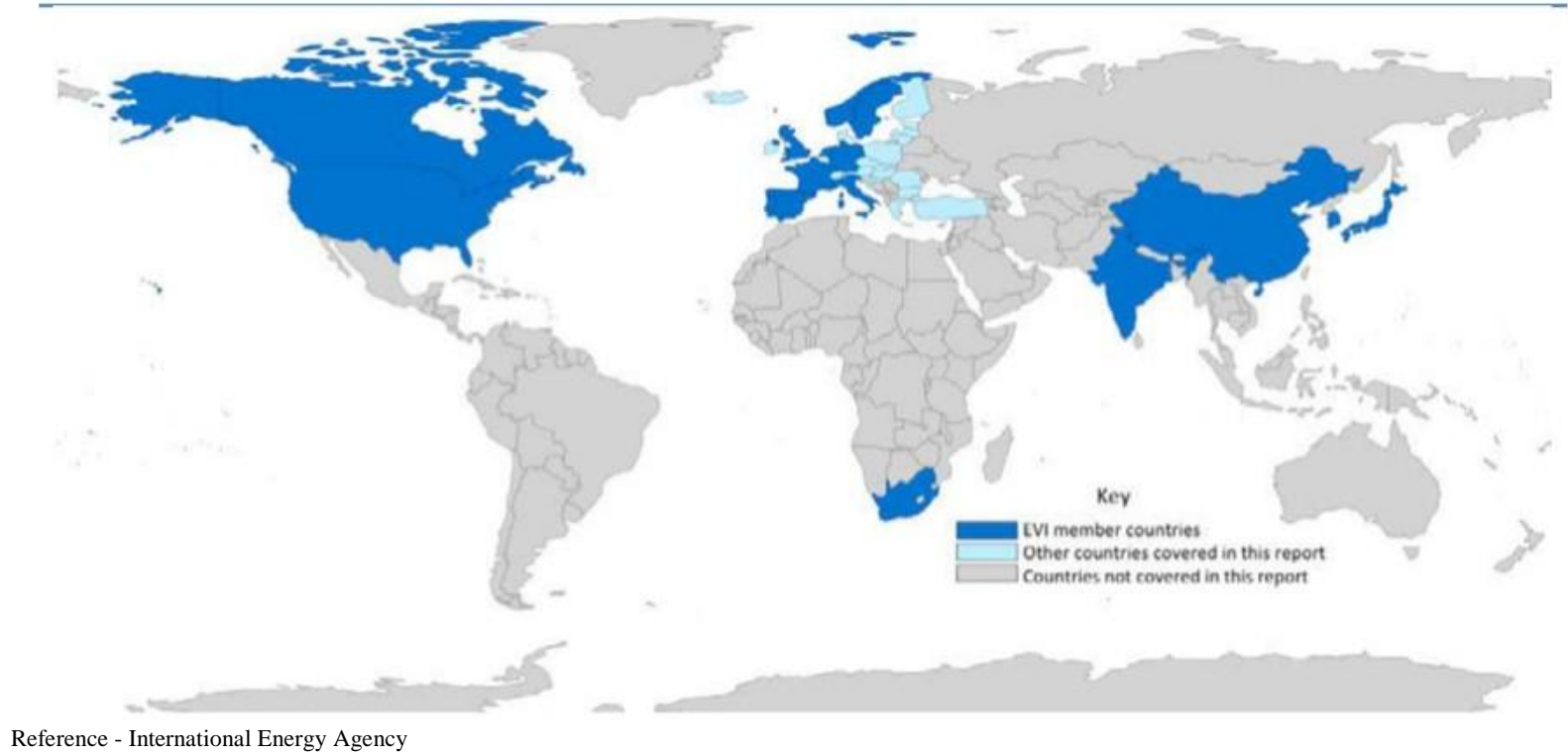

The shared goal of the EVI coalition is to get 20 million EV on the road by 2020 , and to do this the developing world will have to be included. ${ }^{8}$

As seen in the chart above the developing world is largely missing from the EVI coalition. There are many forms promotion takes to prepare the way for global inclusivity. Market evolution continues to grow exponentially, as plug-in hybrids and EV registration and purchase grew 70\% between 2014-15. ${ }^{9}$ However, $90 \%$ of this growth occurred in France, Germany, Japan, the UK, the US, Norway, the Netherlands, and China. Developing nations are as of yet not a part of this movement. Supportive infrastructure for EV is a key aspect of promotion, and charging outlets have been consistently growing to meet the expanded potential, growing from 0.82 million in 2014 to 1.45 million stations in 2015. China has played a large role in the market evolution of EV in this as their fast chargers accounted for $44 \%$ of the increase in charging outlets in $2015 .{ }^{10}$

\section{Issues \& Challenges in Asia\& Developing Nations}

There are many reasons the EV market in Asia and developing nations, for in many ways developing nations take a cue from the influence of China and India. It is only relatively recently that Asia's infrastructure has supported millions of individuals being able to buy cars for the first time. In a short span of time Asian countries have built up their cities, and the factories which produce the millions of cars which have been invested in. These new investments are not soeasily discarded and upgraded, even for the relative affordability of the EVs. ${ }^{11}$ Even as Tesla is facing fierce competition in Asia, a market in which it has to succeed to be a viable going concern. China is the world's largest auto market, Japan the third largest and India the sixth largest.This fierce competition is largely linked to the novelty of gasoline autos not having become familiar enough for the populace to readily remove themselves from this

\footnotetext{
${ }^{8}$ World Bank, 'The China New Energy Vehicles Program,' Worldbank.org, April 2011, Available on: http://siteresources.worldbank.org/EXTNEWSCHINESE/Resources/3196537-1202098669693/EV_Report_en.pdf, (accessed 5 April 2017).

${ }^{9}$ International Energy Agency, 'Global EV Outlook 2016: Beyond one million electric cars,' OECD/IEA 2016, Available on: https://www.iea.org/publications/freepublications/publication/Global_EV_Outlook_2016.pdf, (accessed 5 April 2017).

${ }^{10}$ International Energy Agency, p. 25.

${ }^{11}$ N. Cox, 'Tesla Facing Both Challenges And Opportunities In Asia,' Seekingalpha.com, April 15, 2016. Available on: https://seekingalpha.com/article/3999759-tesla-facing-challenges-opportunities-asia, (accessed 5 April 2017).
} 
coveted cultural icon. However, the market for EV in Asia continues to grow for the middle and upper class who have had a longer exposure to gasoline culture. CEO of the most popular EV, the Tesla, Elon Musk, is pushing this forward by planning to integrate solar energy, battery storage, and EV technology. ${ }^{12}$ Musk knows that Asia is the biggest possible growth market for EVs, for the on the pulse culture of the North (Norway, Netherlands, etc.) has a relatively small population compared to Asia, and will soon have maxed out their buying potential.

One of the key major challenges to EV expansion in Asia is governmental policy which does not always run in accords with the values of the sustainability model. ${ }^{13}$ This is most keenly felt in China, which is a strong trendsetter for Asia. China has a history of making goals without the support in action to accomplish them, and "policies to stimulate demand for EV, deploy vehicle-charging infrastructure, and stimulate investment in technology development and manufacturing capacity also need to be developed."

${ }^{14}$ China has made plans to invest in 100 billion new types of energy vehicles over the next decade, but accomplishing this while allowing for the flux of supply and demand remains a challenge. While new business models are being created to support the EV markets, in Asia and the developing world they have yet to meet with their target market due to the fact that EVs are considered luxury vehicles. ${ }^{15}$ Developing nations as of yet do not have the economic and infrastructure security to take the long view of the saving entailed in EV's sustainable model. This adaption of perception is slowing being influenced by the introduction of electric busses in Asia and the developing world to begin to acclimatize social awareness of the approachability of this technology. ${ }^{16}$

Another challenge to the EV market in Asia and developing countries is that their economic and infrastructure development is at an entirely different place than the EVI consortium. However, due to a lack of environmental regulations the fast industrial build up in Asia and the developing world is translating to deadly pollution rates. For many developing cities, their Air Quality Index (AQI) is hovering near toxic. Currently, nine cities worldwide have an AQI over 100, and almost all of the top 20 most polluted cities are in developing countries. Deli is ranked as the world's most polluted city with an AQI of 153 While EV markets would directly assist with this issue, the changes which would need to be made to accommodate it are currently out of the scope of local production.

In China the EV market is stilted by trade barriers which make EV's more expensive and difficult to obtain. ${ }^{17}$ This may be addressed by beginning to manufacture EVs in China, but so far the government's proposed focus on developing high-end EVs that directly substitute for conventional vehicles has distracted Chinese firms from developing a strong domestic market in lower-performing EVs, particularly low-speed EVs.Inadvertently perhaps this focus has shifted value to electric bicycles, making new EVs seem even more of a luxury item to the average Chinese. ${ }^{18}$

\footnotetext{
${ }^{12}$ N. Cox, 'Tesla Facing Both Challenges And Opportunities In Asia,' Seekingalpha.com, April 15, 2016. Available on: https://seekingalpha.com/article/3999759-tesla-facing-challenges-opportunities-asia, (accessed 5 April 2017).

${ }^{13}$ Electric Vehicle Association of Asia Pacific 'EVAAP,' evaap.org, 2017, Available on: http://www.evaap.org, (accessed 5 April 2017).

${ }^{14}$ World Bank, 'The China New Energy Vehicles Program,' Worldbank.org, April 2011, Available on: http://siteresources.worldbank.org/EXTNEWSCHINESE/Resources/3196537-1202098669693/EV_Report_en.pdf, (accessed 5 April 2017).

${ }^{15}$ K. Kilday, 'Niche for Electric Vehicles in Developing Countries,' Stanford.edu, March 9, 2016, Available on: https://sej.stanford.edu/niche-electric-vehicles-developing-countries, (accessed 5 April 2017).

${ }^{16}$ K. Kilday, 'Niche for Electric Vehicles in Developing Countries,' Stanford.edu, March 9, 2016, Available on: https://sej.stanford.edu/niche-electric-vehicles-developing-countries, (accessed 5 April 2017).

${ }^{17}$ S. Howell et al. 'Leapfrogging or Stalling Out? Electric Vehicles in China.' HKS Faculty Research Working Paper Series, May 2014. Available on: http://web.hks.harvard.edu/publications, (accessed 5 April 2017).

${ }^{18}$ S. Howell et al. p. 1 .
} 
Further to above, if we consider the impact of EVs on fuel consumption, then one million electric vehicles per year would displace about 50,000 barrels per day of oil consumption; 10 million of them would remove 500,000 barrels from the market a day. But even if we keep on replacing 10 million gasolinepowered cars with electric ones each year for the next 10 years, it will take a very long time to make a dent in the global vehicle fleet of 1.1 billion cars and trucks and the 100 million barrels of oil per day they consume. This will not change unless developing countries take a lead in this transformation by starting to adopting electric vehicles en masse ${ }^{19}$

\section{Possible Solutions of EV promotion}

Many different solutions are being proposed and implemented to address the challenges to developing an EV market in Asia and the developing world. ${ }^{20}$ Improving the social awareness of the style, accessibility, and viability of the EV is occurring through exposure to Asian markets through advertising and car shows. ${ }^{21} \quad$ Norway's proposal to ban all vehicles which are not electric will not help the global image of EVs, as it threatens not only domestic industry, but the viability of current vehicle investments. Added to this the public by and large do not enjoy being forced to buy something so new, and the relative cost of EVs would not allow a good portion of the population to even have a car if more nations adopted such stringent policies. ${ }^{22}$

Currently, the high energy storage cost is considered to be the Achilles heel for extensive development of Electric Vehicles, similar to renewable energy development. High demand for batteries will lead to the development of integrated battery supply chains, which are bound to considerably lower the costs of storage. Lower storage costs will in turn help lower landed renewable energy costs and make its evacuation more efficient. Within the US and China, the adoption of EVs has led to the setting up of battery manufacturing: China has $16.7 \mathrm{GWh}$ of battery capacity commissioned and $35.1 \mathrm{GWh}$ in development. Similarly, the US has $3.8 \mathrm{GWh}$ of capacity commissioned and $36.2 \mathrm{GWh}$ in development ${ }^{23}$.

EV purchase and investment of infrastructure has been supported in the US through the EP Act of 2005 which offered many tax incentives for purchasing alternative energy vehicles. ${ }^{24}$ When possible, perhaps with the help of international subsidiary from climate support systems, Asia and developing nations could pass similar legislation which would encourage the public to reevaluate the cost-benefit of EVs. Many nations have instituted programs of having all their public and taxi transport be electric, and this could go a long way towards socializing the different approach as well as beginning to implement infrastructure support in developing nations. ${ }^{25}$

\footnotetext{
${ }^{19}$ Sohail Hasnie, Principal Energy Specialist, Central and West Asia Department, ADB, 'Developing Asia can start an electric car revolution' blog on ADB website, Available on; https://blogs.adb.org/blog/developing-asia-can-start-electric-car-revolution

${ }^{20} \mathrm{Han}, \mathrm{Y}$. et al. 'Current status and future development of electric vehicle in China,' Journal of Chemical and Pharmaceutical Research, 2014, Vol. 6, no. 7, pp. 284-288. Available on: http://www.jocpr.com/articles/current-status-and-future-developmentof-electric-vehicle-in-china.pdf, (accessed 5 April 2017).

${ }^{21}$ Lee, Y., 'Future of Asian luxury cars, electric vehicles at auto show,' CNBC, March 30, 2017, Available on: http://www.cnbc.com/2017/03/30/the-associated-press-future-of-asian-luxury-cars-electric-vehicles-at-auto-show.html, (accessed 5 April 2017).

${ }^{22}$ N. Marro, et al. 'Opportunities and Challenges in China's Electric Vehicle Market,' China Business Review 2 February 2015, Available on: https://www.chinabusinessreview.com/opportunities-and-challenges-in-chinas-electric-vehicle-market/, (accessed 5 April 2017).

${ }^{23}$ Ernst \& Young (EY) - Electric Vehicles adoption: potential impact in India- A Power and Utilities perspective http://www.ey.com/Publication/vwLUAssets/EY-ev-adoption-potential-impact-in-India-july-2016/\$FILE/EY-ev-adoptionpotential-impact-in-India-july-2016.pdf

${ }^{24}$ Z. Xingping, et al., 'Policy Incentives for the Adoption of Electric Vehicles across Countries,' Sustainability vol. 6, 2014, pp. 8056-8078. Available on: file:///C:/Users/Grace\%20Pollari/Downloads/sustainability-06-08056\%20(1).pdf (accessed 5 April 2017).

${ }^{25}$ F., Wolter, 'Next Generation Solutions for Clean Air and Sustainable Transport in Asia:
} 


\section{Conclusion, Recommendations and Actions Required}

Major players and global trend setters must be of one mind in regards to EV implementation. Much like the UN seeks sustainability and peace for all its member states, the EVI should begin to seek recruitment in Asia and the developing nations to increase outreach of this sustainable market. ${ }^{26}$ The benefits of EV are substantial and lasting, but would benefit from a gradual transition from gasoline, to hybrid, to fully EV. For those who do not desire their vehicle investment to be lost programs could be established for upgrading vehicles to a sustainable model. Continued socialization with EV technology must be maintained in Asia and developing nations as exposure is key for developing comfortability with the emerging changes.

Greater education of the reality of climate change must be made a part of all curriculum and public policy so that EVs do not seem like an extremity, but a reality in the face of dangerous $\mathrm{CO} 2$ levels. Continued tax incentives and community building must be expanded throughout Asia and the developing world with a linked emphasis on personal accountability and the empowerment of free will maximized with global will.

For the accelerated growth of EV's in Asian developing countries includes, it is very much necessary that all the stakeholders, including governments at all levels, businesses, organizations and others endorse the common vision and subsequently prepare their individual or collective efforts of EV promotion and commercialization action plans which will also contribute to the Paris Climate Declaration of GHG emission reductions and combat global warming.

\section{References}

1. Asian Development Bank (ADB) - Addressing Climate Change in Transportof Asian Developing countries-https://www.adb.org/sectors/transport/key-priorities/climate-change

2. Cox, N., 'Tesla Facing Both Challenges And Opportunities In Asia,' Seekingalpha.com, April 15, 2016. Available on:https://seekingalpha.com/article/3999759-tesla-facing-challengesopportunities-asia, (accessed 5 April 2017).

3. Electric Vehicle Association of Asia Pacific 'EVAAP,' evaap.org, 2017, Available on:http://www.evaap.org, (accessed 5 April 2017).

4. Ernst \& Young (EY) - Electric Vehicles adoption: potential impact in India- A Power and Utilities perspective - http://www.ey.com/Publication/vwLUAssets/EY-ev-adoption-potentialimpact-in-India-july-2016/\$FILE/EY-ev-adoption-potential-impact-in-India-july-2016.pdf

5. Han, Y. et al. 'Current status and future development of electric vehicle in China,' Journal of Chemical and Pharmaceutical Research, 2014, Vol. 6, no. 7, pp. 284-288. Available on:http://www.jocpr.com/articles/current-status-and-future-development-of-electric-vehicle-inchina.pdf, (accessed 5 April 2017).

Electric Mobility,' 8th Intergovernmental Regional Environmentally Sustainable Tranport Forum in Asia 19 to 21 November 2014 Bandaranaike Memorial International Conference Hall, Colombo: Sri Lanka. Available on: http://www.uncrd.or.jp/content/documents/21488EST-P2-BGP_InnoZ.pdf, (accessed 5 April 2017).

${ }^{26}$ G. Masiero et al. 'Electric vehicles in China: BYD strategies and government subsidies,' RAI Revista de Administração e Inovação Vol. 13, No. 1, 2016, pp. 3-11, Available on: http://www.sciencedirect.com/science/article/pii/S1809203916300018, (accessed 5 April 2017). 
6. Sohail Hasnie, Principal Energy Specialist, Central and West Asia Department, ADB, 'Developing Asia can start an electric car revolution' blog on ADB website, Available on; https://blogs.adb.org/blog/developing-asia-can-start-electric-car-revolution

7. Howell, S. et al. 'Leapfrogging or Stalling Out? Electric Vehicles in China.' HKS Faculty Research Working Paper Series, May 2014. Available on: http://web.hks.harvard.edu/publications, (accessed 5 April 2017).

8. International Energy Agency, 'Global EV Outlook 2016: Beyond one million electric cars,' OECD/IEA 2016, Available on:https://www.iea.org/publications/freepublications/publication/Global_EV_Outlook_2016.pdf, (accessed 5 April 2017).

9. Kilday, K. 'Niche for Electric Vehicles in Developing Countries,' Stanford.edu, March 9, 2016,Available on:https://sej.stanford.edu/niche-electric-vehicles-developing-countries, (accessed 5 April 2017).

10. Lee, Y., 'Future of Asian luxury cars, electric vehicles at auto show,' $C N B C$, March 30, 2017,Available on:http://www.cnbc.com/2017/03/30/the-associated-press-future-of-asian-luxurycars-electric-vehicles-at-auto-show.html, (accessed 5 April 2017).

11. Marro, N. et al. 'Opportunities and Challenges in China's Electric Vehicle Market,' China Business Review.Available on:https://www.chinabusinessreview.com/opportunities-andchallenges-in-chinas-electric-vehicle-market/.

12. Masiero, G. et al. 'Electric vehicles in China: BYD strategies and government subsidies,' RAI Revista de Administração e InovaçãoVol. 13, No. 1,2016, pp. 3-11, Available on:http://www.sciencedirect.com/science/article/pii/S1809203916300018, (accessed 5 April 2017).

13. UNFCCC- Paris Declaration on Electro-Mobility and Climate Change \& Call to Action. Available on: http://newsroom.unfccc.int/media/521376/paris-electro-mobility-declaration.pdf

14. Wolter, F., 'Next Generation Solutions for Clean Air and Sustainable Transport in Asia:

a. Electric Mobility,' 8th Intergovernmental Regional Environmentally Sustainable Transport Forum in Asia.Available on:http://www.uncrd.or.jp/content/documents/21488EST-P2-BGP_InnoZ.pdf, (accessed 5 April 2017).

15. World Bank, 'The China New Energy Vehicles Program,' Worldbank.org, April 2011, Available on:http://siteresources.worldbank.org/EXTNEWSCHINESE/Resources/31965371202098669693/EV_Report_en.pdf.

16. Xingping, Z. et al., 'Policy Incentives for the Adoption of Electric Vehicles across Countries,'Sustainability vol. 6, 2014, pp. 8056-8078. Available on: file:///C:/Users/Grace\%20Pollari/Downloads/sustainability-06-08056\%20(1).pdf

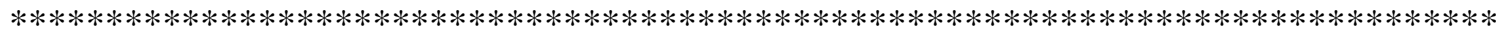

\section{Hemant Nandanpawar}

Hemant is a Clean Energy, Climate Change and Sustainable Development expert, working as Senior Director - Advisory Services of Ernst \& Young LLP, Manila, Philippines. Ernst \& Young is a global Big four global firm, with presence in more than 190 countries.

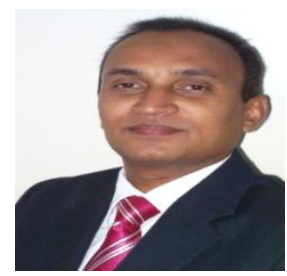

Hemant is Post graduate in Sustainable Business from Cambridge University, United Kingdom (U.K) and an International Certified Renewable Energy Expert from Frankfort School, Germany. He is an Industrial Engineering graduate with Masters of Technology (M.Tech) in Energy Management, MBA in Finance 
and a Certified Energy Manager \& Energy Auditor of Bureau of Energy Efficiency (BEE), India.Hemant has extensive local and International work experience in the area of Energy Conservation \& Management, Renewable Energy, Project Finance, Policy and Strategy studies, Climate Change, Carbon and Climate Finance, Sustainability, Capacity Building activities and Sustainable Development. He has rich experience of successful completion of more than 250 consulting project assignments of diverse areas. Towards his contribution in the field of Energy Management and Climate Change at National and International level, he has been conferred with prestigious Awards/Appreciations including;

- Member of UNFCCC Methodologies Panel, Bonn, Germany for the year 2011-12

- $\quad$ State Government of Andhra Pradesh Energy Appreciation Award, 2008

- Government of Maharashtra Award 'Excellence in Energy Management' in 2007

- Youngest recipient of 'DSK Energy Award' of Institution of Engineers India (IEI) in 2006

His past working experience includes his long international stint with Asian Development Bank (ADB), Manila-Philippines as an International Specialist for more than 6 years. He is a Methodologies Expert and also served as Member of Global CDM Methodologies Panel (MP) of United Nations Framework Convention for Climate Change (UNFCCC), Bonn, Germany. He worked with MITCON Limited and Kirloskar Consultants Limited (KICONS), Pune, during his early years of professional career.Hemant has published many papers and articles in national and international publications and as a subject matter expert and a well-established capacity building trainer, regularly participating to national and international conferences, workshops and capacity building programs. 